\title{
Применение волоконных лазеров для формирования покрытий из порошков переходных и редкоземельных металлов в постоянном магнитном поле
}

\author{
Ю.Н. Кульчин, А.И. Никитин*, Е.П. Субботин, А.А. Костянко, \\ Д.С. Пивоваров, Д.С. Яцко \\ Институт автоматики и прочессов управления ДВО РАН \\ E-mail: anikitin@iacp.dvo.ru
}

DOI:10.31868/RFL2018.189-190

Способы формирования покрытий из переходных и редкоземельных металлов, например, системы Sm-Co, представляют особый интерес, поскольку обладают высокой намагниченностью, высокой коэрцитивной силой, высокой температурой Кюри $\left(800^{\circ} \mathrm{C}\right)$ и являются одним из основных магнитных материалов для высокотемпературных применений. В отличие от традиционных способов выращивания эпитаксиальных тонких пленок $\mathrm{SmCo}_{5}[1,2,3]$, способ формирования ферромагнитных покрытий в системе $\mathrm{Sm}-\mathrm{Co}$ методом лазерной наплавки, с использованием волоконных лазеров средней мощности, на не ориентированных металлических подложках представляет интерес как фундаментальной, так и с прикладной точек зрения.

Экспериментальные исследования процессов создания покрытий из порошкового материала $\mathrm{Sm}-\mathrm{Co}$ проводились с использованием роботизированного лазерного комплекса [4] в постоянном магнитном поле в защитной среде из инертных технологических газов методом лазерного спекания (рисунок 1).

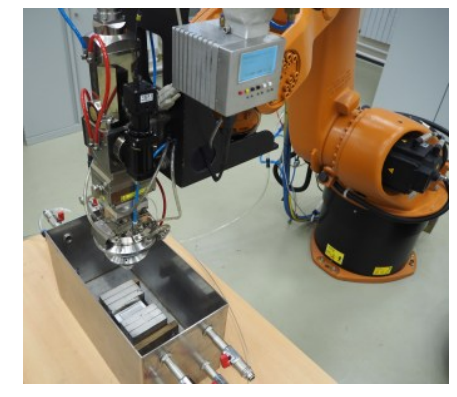

a

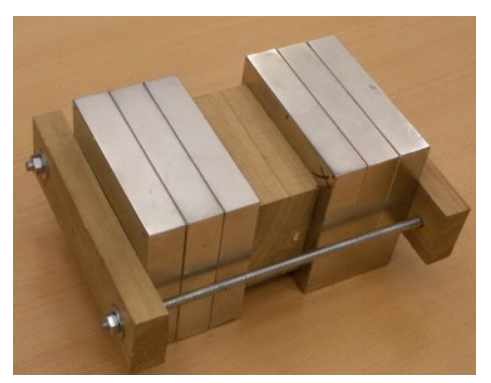

6

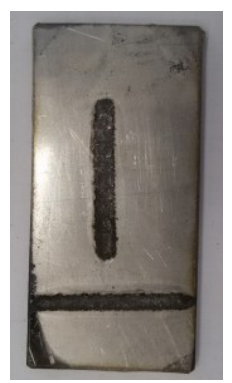

B

Рисунок 1 - Роботизированный лазерный комплекс для формирования покрытий из порошкового материала $\mathrm{Sm}-\mathrm{Co}(\mathrm{a})$, система из постоянных магнитов для создания магнитного поля индукцией 0,5 Тл (б), внешний вид линий, наплавленных вдоль и поперек силовых линий магнитного поля (в).

Дуралюмин и нержавеющая сталь использовались в качестве подложек. Объектом исследования являлся процесс формирования слоев из порошка самария с составом rho-Sm ( $\sim 49 \%$ at.), hex-Sm ( $\sim 48 \%$ at.) и $\mathrm{Sm}_{2} \mathrm{C}_{3}$ ( $<3$ at. \%) и порошка Со ( 99.9 at. \%), которые наплавлялись сфокусированным лазерным пучком на подготовленные поверхности подложек. Методом рентгенофлуоресцентного анализа было установлено, что в образце $\mathrm{Sm}$ в виде примесей содержатся элементы Si и С. Исходные порошки (Sm и Сo), как показали магнитные низкотемпературные измерения, имеют ферромагнитные (Со) и парамагнитные $(\mathrm{Sm})$ свойства $[5,6]$. 
В образце, сформированном в постоянном магнитном поле $\left(\mathrm{Sm}_{37} \mathrm{Co}_{63}\right)$ (рисунок 2 а,б) и вырезанном перпендикулярно валику наплавки, наблюдается достаточно сильное изменение микроструктуры образца.

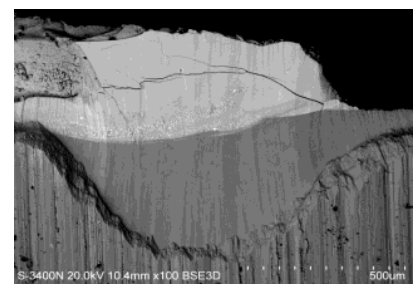

a

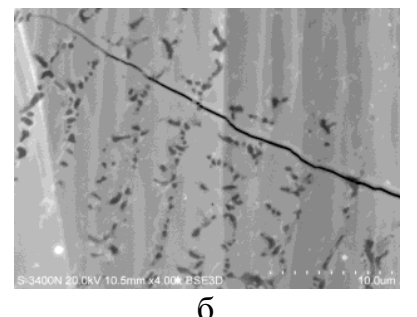

6

Рисунок 2 - Образец $\mathrm{Sm}_{37} \mathrm{Co}_{63}$ со срезом поперек наплавленного валика полученного при воздействии продольного магнитного поля (a), (б) - увеличенное изображение участка тамплета.

Анализируя микроструктуру полученного шлифа, можно обратить внимание на то, что плотность вытянутых зерен уменьшается и появляется светлая область с небольшими вкраплениями темных зерен, обедненных самарием. В центре светлой области (рисунок 2 б) заметно увеличивается концентрация кобальта и самария. Средний состав можно представить формулой: $\mathrm{Fe}_{13.5} \mathrm{Co}_{60.9} \mathrm{Sm}_{9.4} \mathrm{Ni}_{4.2} \mathrm{Cr}_{1.5} \mathrm{O}_{5.0} \mathrm{C}_{5.9}$.

На срезе образца $\mathrm{Sm}_{37} \mathrm{Co}_{63}$, вырезанном вдоль валика наплавки наблюдается чередование областей сеточной структуры с тенденцией увеличения концентрации железа, хрома и никеля и уменьшение концентрации самария и кобальта: $\mathrm{Fe}_{32.3} \mathrm{Co}_{41.4} \mathrm{Sm}_{7.5} \mathrm{Ni}_{5.5} \mathrm{Cr}_{7.5}$ (рисунок $3 \mathrm{a}$, б).

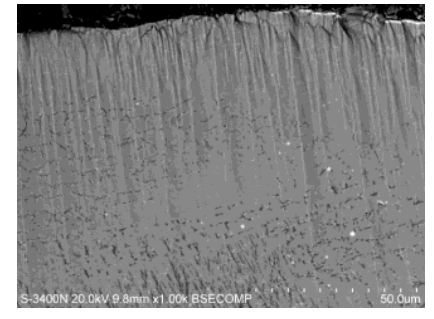

a

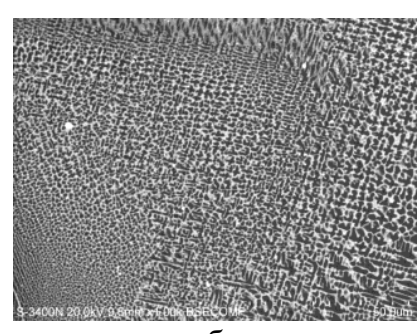

6

Рисунок 3 - Образец $\mathrm{Sm}_{37} \mathrm{Co}_{63}$ со срезом вдоль наплавленного валика полученного при воздействии продольного магнитного поля (а), (б) - увеличенное изображение участка тамплета.

В процессе исследований изучено влияние различных факторов на формирование покрытий Sm-Со на немагнитных подложках методом аддитивных технологий при использовании высокоэнергетического лазерного излучения с длиной волны 1.07 мкм. Исследована технологическая база для развития методов создания локальных магнитных зон из порошков переходных и редкоземельных металлов в постоянном магнитном поле на немагнитных подложках.

\section{Литература}

[1] M. Benaissa, K. M. Krishnan, E.E. Fullerton et al, IEEE Transactions on Magnetics, 34, 1204-1206 (1998).

[2] J.P. Liu, D.J. Sellmyer et al, Journal of Applied Physics 45, 4812-4814 (1999).

[3] M. Seifert, V. Neu, L. Schultz, Applied Physics Letters, 94, 022501-1 - 022501-3 (2009).

[4] Kulchin Y.N., Galkin N.G., Subbotin E.P., et al, SSP, 245, 230-237 (2015).

[5] Galkin, N. G., Kulchin, Y. N., Nikitin, A. I., et al, Proceeding. of SPIE Vol. 10176, art.nmb. 1017622-1, doi: 10.1117/12.2268259 (2016).

[6] Galkin, N. G., Kulchin, Y. N., Stebliy, et al, Proceeding. of SPIE Vol. 10176, art.nmb. 1017623-1, doi: $10.1117 / 12.2268261$ (2016). 